Food and Agriculture Organization of the United Nations

\title{
The effects of global value chain (GVC) participation on the economic growth of the agricultural and food sectors
}

Background paper for The State of Agricultural Commodity Markets (SOCO) 2020 



\title{
The effects of global value chain (GVC) participation on the economic growth of the agricultural and food sectors
}

\author{
Background paper for \\ The State of Agricultural Commodity \\ Markets (SOCO) 2020 \\ Pierluigi Montalbano \\ Associate Professor \\ Sapienza University of Rome, Italy and \\ Sussex University, the United Kingdom of Great Britain and Northern Ireland \\ and \\ Silvia Nenci \\ Associate Professor \\ Roma Tre University
}

Food and Agriculture Organization of the United Nations Rome, 2020 


\section{Required citation:}

Montalbano, P. and Nenci, S. 2020. The effects of global value chain (GVC) participation on the economic growth of the agricultural and food sectors - Background paper for The State of Agricultural Commodity Markets (SOCO) 2020. Rome, FAO. https://doi.org/10.4060/cb0714en

The designations employed and the presentation of material in this information product do not imply the expression of any opinion whatsoever on the part of the Food and Agriculture Organization of the United Nations (FAO) concerning the legal or development status of any country, territory, city or area or of its authorities, or concerning the delimitation of its frontiers or boundaries. The mention of specific companies or products of manufacturers, whether or not these have been patented, does not imply that these have been endorsed or recommended by FAO in preference to others of a similar nature that are not mentioned.

The views expressed in this information product are those of the author(s) and do not necessarily reflect the views or policies of FAO.

ISBN 978-92-5-133200-9

(C) FAO, 2020

\section{(1) $\Theta($ \\ BY NC SA}

Some rights reserved. This work is made available under the Creative Commons Attribution-NonCommercial-ShareAlike 3.0 IGO licence ICC BYNC-SA 3.0 IGO; https://creativecommons.org/licenses/by-nc-sa/3.0/igo/legalcode).

Under the terms of this licence, this work may be copied, redistributed and adapted for non-commercial purposes, provided that the work is appropriately cited. In any use of this work, there should be no suggestion that FAO endorses any specific organization, products or services. The use of the FAO logo is not permitted. If the work is adapted, then it must be licensed under the same or equivalent Creative Commons licence. If a translation of this work is created, it must include the following disclaimer along with the required citation: "This translation was not created by the Food and Agriculture Organization of the United Nations (FAO). FAO is not responsible for the content or accuracy of this translation. The original [Language] edition shall be the authoritative edition."

Disputes arising under the licence that cannot be settled amicably will be resolved by mediation and arbitration as described in Article 8 of the licence except as otherwise provided herein. The applicable mediation rules will be the mediation rules of the World Intellectual Property Organization http://www.wipo.int/amc/en/mediation/rules and any arbitration will be conducted in accordance with the Arbitration Rules of the United Nations Commission on International Trade Law (UNCITRAL).

Third-party materials. Users wishing to reuse material from this work that is attributed to a third party, such as tables, figures or images, are responsible for determining whether permission is needed for that reuse and for obtaining permission from the copyright holder. The risk of claims resulting from infringement of any third-party-owned component in the work rests solely with the user

Sales, rights and licensing. FAO information products are available on the FAO website (www.fao.org/publications) and can be purchased through publications-sales@fao.org. Requests for commercial use should be submitted via: www.fao.org/contact-us/licence-request. Queries regarding rights and licensing should be submitted to: copyright@fao.org. 


\section{Contents}

Acknowledgements V

Abbreviations and acronyms .........................................................................................................................vi

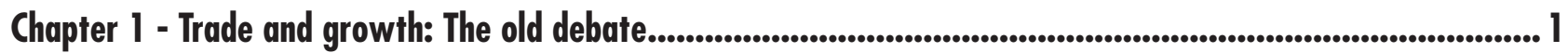

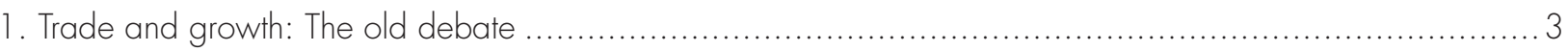

Chapter 2 - The effects of agriculture and food global value chain (GVC) participation: some preliminaryevidence 5

2. The effects of agriculture and food global value chain (GVC) participation: some preliminary evidence ........7

Chapter 3 - Some preliminary policy insights........................................................................................... 11

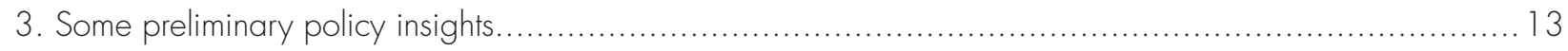

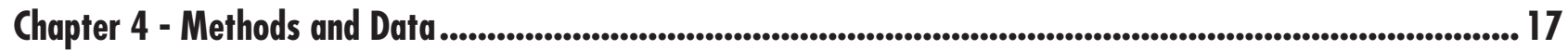

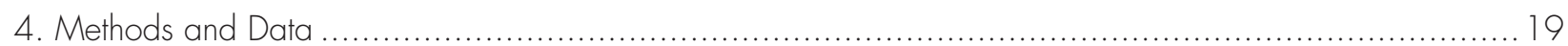

Chapter 5 - A global assessment of the linkages between both global value chain (GVC) participation

(and positioning) and economic growth in the agricultural sector

5. A global assessment of the linkages between both global value chain (GVC) participation

(and positioning) and economic growth in the agricultural sector ......

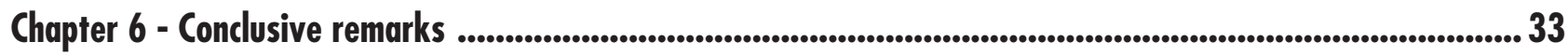

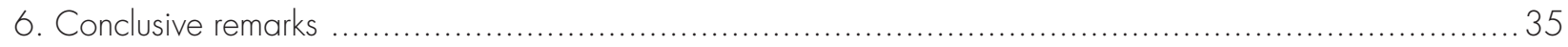

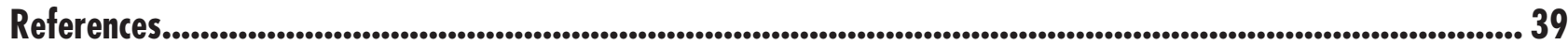

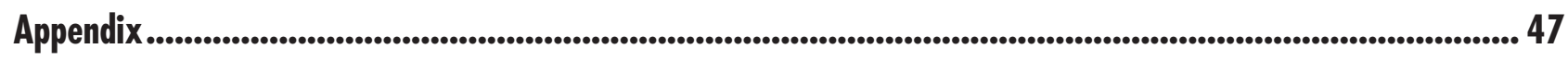

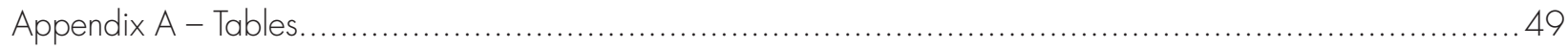




\section{Tables}

Table 1

Table 2

Table 3

Table 4

Table 5

Table A 1

\section{Figure}

Figure 1
Panel estimates (period 1995-2015). 25

Panel estimates (period 1995-2015) by income groups............................... 26

Panel estimates by disentangling backward and forward GVC (period 1995-2015)....28

2SLS estimates 29

Panel estimates for upstreamness and downstreamness (period 1995-2015) 30

Panel estimates (period 2009-2015). 49

Plot of the estimated coefficients (and the respective confidence intervals) of the relationship between agriculture value added per worker and GVC participation in agriculture (panel a) and food (panel b) by geographical clusters

(Western Europe is the benchmark category) - period 1995-2015 


\section{Acknowledgements}

Trade liberalization has long been advocated as a means to foster growth and welfare. In developing countries, the expansion of global value chain (GVC) participation of agriculture and food sectors could support transformation from a subsistence-oriented and farm-centred system to a commercialized, productive and off-farm centred one.

While empirical evidence examining the linkages between GVC participation and economic performance in the agricultural sector has traditionally relied on case studies at the product level, the availability of new aggregate data on trade in value added, now provides an unprecedented opportunity to carry out a global empirical assessment of the linkages.

The present paper examines new measures of GVCs participation and positioning from the EORA panel data for the period 1995-2015 (Nenci, 2020) and tests their effects on changes in agriculture value added per worker. The results show that changes in GVC participation are, on average and ceteris paribus, positively associated with changes in agriculture value added per worker, net to time-invariant confounders, whereas mixed results are found on the effects of countries' positioning along the value chain. In the conclusive remarks, the authors argue that import tariff and non-tariff barriers - including barriers to service trade - should be seen as the first obstacle to increase GVC participation and improve domestic value added. The presence of signs of heterogeneity by geographical location confirms that general universal recipes do not exist. 


\begin{tabular}{|c|c|}
\hline AfCFTA & African Continental Free Trade Area \\
\hline MNCs & Multinational firms \\
\hline NTMs & Non-tariff measures \\
\hline OECD & Organization for Economic Co-operation and Development \\
\hline PSE & Producer support estimate \\
\hline RTAs & Regional trade agreements \\
\hline SPS & Sanitary and phytosanitary \\
\hline TBT & Technical barriers to trade \\
\hline VA & Value added \\
\hline WIOD & World Input Output Database \\
\hline WTO & World Trade Organization \\
\hline
\end{tabular}




\section{CHAPTER 1}

Trade and growth: The old debate 



\section{Trade and growth: The old debate}

According to theory, international trade improves resource allocation, lowers prices for consumers, and leads to a more efficient production. An open trade regime also encourages the integration of the economy into the global system and imports of modern technology, which results in productivity improvements (see, inter alia, Alcala and Ciccone, 2004 and Badinger, 2008). Accordingly, international organizations advocate policy reforms centred on trade liberalization to foster growth and welfare (Montalbano, 2011).

Seminal empirical work established a consistent and significant positive correlation between trade liberalization, growth, and poverty reduction (Edwards, 1993; Frankel and Romer, 1999; Sachs and Warner, 1995; Dollar and Kraay, 2002, 2004; Cline, 2004; Winters, 2004). The drawbacks to trade openness were acknowledged basically in terms of short and medium run adjustment costs (Winters, 2004; Winters and Martuscelli, 2014). The pervasive effects of trade openness on poverty and inequality, even in the long run, have also been acknowledged (Goldberg and Pavcnik, 2004; Lundberg and Squire, 2003; McCulloch, Winters and Cirera, 2001; Winters et al., 2004).

A recent review of the literature on the links between trade liberalization and economic growth (Irwin, 2019) concludes that developing countries show measurable economic payoffs from trade liberalizations. A similar review by Winters and Martuscelli (2014) shows that such results are dependent on both the nature of trade reforms and the type of livelihoods of the poor. Meissner (2014), providing a review of the debate about globalization and economic growth from a historical perspective, concludes that such a relationship is conditional to a set of complementary factors that might influence the gains from trade.

Scholars have pointed out that the nature of international trade has recently changed, passing "from trade in goods to trade in tasks" (Grossman and Rossi-Hansberg, 2008). We still do not know whether or not this calls for a different paradigm (namely, different trade patterns), as argued by Baldwin (2013), and, consequently, for a different relationship between trade and economic performances of partner countries (see Salvatici and Nenci, 2017 for a review). 



\section{CHAPTER 2}

The effects of agriculture and food global value chain (GVC) participation: some preliminary evidence 



\section{The effects of agriculture and food global value chain (GVC) participation: some preliminary evidence}

Over the last decades, global value chains (GVCs) participation has shaped production and specialization patterns worldwide in all sectors, including the agricultural and food sectors. These latter have recently changed their trade composition: from the dominance of traditional commodities to increasing trade in higher-value processed products (Taglioni and Winkler, 2016). According to the most recent literature, thanks to the "GVC revolution", even small countries with limited capacities or resources have a chance to participate in GVCs and benefit from global trade (Minten et al., 2009; Cattaneo et al., 2013; Swinnen and Vandeplas, 2014; Swinnen, 2016). Notwithstanding considerable variation across sectors and countries, agriculture sectors participate in value chains mainly as suppliers of raw materials used in other production processes, whereas food sectors participate mainly in terms of sourcing inputs from around the globe (Greenville et al., 2017). The increasing importance of global agricultural trade registered during the past three decades comes with changes in the way GVCs are organized, with increasing levels of vertical coordination, upgrading of the supply base, and the increased importance of large multinational food companies (McCullough et al., 2008). A relatively small number of companies now organize the global supply of food and link small producers in developed or developing countries to consumers all over the world (Humphrey and Memedovic, 2006; Gereffi and Lee, 2012).

Much empirical evidence on agri-food GVCs relies on case studies at the product level to assess the impact on national economies (Salvatici and Nenci, 2017). These studies highlight that the development of agri-food chains can be an important opportunity to increase rural income, reduce rural poverty and foster pro-poor growth (Maertens and Swinnen, 2009; Reardon et al., 2009; Rao and Qaim, 2011; Rao, Brummer and Qaim, 2012). From a macro point of view, a new and growing literature has emerged to describe the competitiveness of a country and/or its industries by looking at their production of value added as well as their level of integration into GVCs. Inter-country input-output tables and a full matrix of bilateral trade flows are now used to determine the trade in value added data and calculate new indicators (Salvatici and Nenci, 2017). These aggregate analyses show that half of the current agro-food trade can be considered of intermediate usage for global production processes (OECD, 2016). They also show an increase of GVC participation of the agri-food sectors with rising trade in both intermediate and final goods (although growth in intermediates has been strongest for food products rather than agricultural products, Nenci, 2020). Finally, they show that, despite low trade shares at the global level, the sub-Saharan African agricultural sector turns out to be deeply involved in GVC participation and that the relevance of its international linkages is increasing over time. Participation is, however, still limited to upstream production stages of the chain and mainly driven by the European market (Foster-McGregor et al., 2015; Balié et al., 2019). Complexity - in terms of diversity of sourcing from GVCs - has also increased over time. Another change concerns the distribution of labour returns from agro-food participation that tends to be primarily captured by unskilled workers. This is due to a significant shift in trade from and towards developing and emerging countries that use higher amounts of labour in the production of their exports compared to developed regions (Greenville et al., 2019a). Furthermore, the participation in agricultural global value chains may affect the structural transformation of participating countries, transforming their economies from the agricultural sector directly to the service sector, by leapfrogging the manufacturing sector (Lim, 2019). 
The common wisdom is that the emergence of GVCs can represent a golden opportunity for supporting the ongoing transformations of developing countries, especially in agriculture and food markets, which could move from a subsistence-oriented and farm-centred system to a more commercialized, productive and off-farm centred one (Greenville et al., 2017; Del Prete et al., 2017; Montalbano et al., 2018a). GVC participation is indeed supposed to open access to unprecedented flows of knowledge, capital, and, in particular, sophisticated inputs (IMF 2015; Montalbano et al., 2018b), which can lead to an accelerated and widespread path of structural transformation and income growth. By generating higher incomes, and because of technology spillovers on food production, participation in the export chains is also supposed to improve income stability and the food security of smallholder households (Cattaneo and Miroudot, 2015; Swinnen, 2014; Swinnen and Kuijpers, 2017; Reardon et al., 2009; Barrett et al., 2017).

Notwithstanding such positive perspectives, most of the empirical analyses underline that getting access to, involvement, and participation in a GVC is not an easy task. Increasing standards in international markets may exclude smallholders and family farms from value chains (Dolan and Humphrey, 2000; Reardon et al., 2009; Gibbon, 2003; Berdegué et al., 2005; Jaffee and Masakure, 2005; Belton et al., 2011; Bamber and Fernandez-Stark, 2014). Small farmers may be unable to comply with stringent requirements due to a lack of technical and financial capacity (Reardon et al., 2001). This may induce traders and processing firms to reduce sourcing from small suppliers. Also, transaction costs for monitoring compliance with standards may be very high in the case of sourcing from smallholders (Swinnen, 2016). Such requirements can represent significant barriers to market access, which make them prohibitive for many small and mediumsized producers (Lee et al., 2012; Montalbano et al., 2018a). In many developing countries, other obstacles can threaten competitiveness such as weak regulatory institutions, poorly designed and implemented sanitary and phytosanitary regulations, inadequate transportation, power and water infrastructure, and the absence of important value chain actors (Hazell et al., 2010). Consequently, small- and medium-sized producers are generally not well-positioned to respond to changes in market structures and risk being marginalized (Dolan and Humphrey, 2004; Maertens and Swinnen, 2009; Lee et al., 2012). In summary, the empirical evidence yields a mixed picture on the capability of countries - and specifically small farmers $\neg-$ to join agri-food value chains and exploit their economic benefits (Salvatici and Nenci, 2017).

Despite the spreading of strategies for "joining the GVCs", positive impacts on the domestic economy should not be taken for granted. Several empirical studies have observed significant effects only for middle and high-income countries. Conversely, minimal economic benefits have been observed for small or less developed countries that are characterized by low capabilities and low absorptive capacity (Fagerberg et al., 2018; Kummritz, 2015). This is in part influenced by the governance modalities of the value chain and the degree of control and power asymmetries along the chain (Greenville et al., 2017). When a lead firm exerts its market power by specifying the rules of production, suppliers with weak local capabilities and weak national innovation systems may operate through modalities dictated by the dominant player and suffer from international competition. The increasing need of compliance with global standards on issues such as health and safety, quality management and social and environmental concerns, couples with a set of global challenges in changing trade policy regimes, as well as the emerging importance of the service aspect of product supply related to concepts of time delivery, reliability, and traceability (Nadvi, 2004). All these elements influence the nature of spillovers and potential productivity gains deriving from GVC participation, especially for firms situated upstream of the value chain. 
In this framework, some studies have analysed the role of intermediate goods in generating a positive impact on industries' total factor productivity (see, inter alia, Bas and Strauss-Kahn, 2014; Halpern et al., 2015; Olper et al., 2015). Empirical results from Southeast Asia suggest that foreign sourcing in the production of exports is a complement to, rather than a substitute for, the creation of domestic value added in exports (Lopez-Gonzalez, 2016). Other studies confirming the positive relationship between the use of foreign imported inputs and increase in firm productivity growth in developing countries are Amiti \& Konings (2007) for Indonesia; Kasahara \& Rodrigue (2008) for Chilean manufacturing plants; Halpern et al. (2011) for Hungary; Topalova and Khandelwal (2011) for India; Montalbano et al. (2018b) for Latin America and Caribbean. Kowalski et al. (2015) highlight that the effect of GVC participation on domestic value added depends on both backward and forward linkages. In other words, either source foreign inputs for export production or provide inputs to foreign partners for their export production tend to bring about economic benefits.

Milberg and Winkler (2010) made a useful distinction between economic upgrading, usually defined in terms of efficiency of the production process or characteristics of the product or activities performed (Humphrey and Schmitz, 2002), and social upgrading often referred to outcomes related to employment and pay, gender and the environment. Somewhat curiously, the economic upgrading path has been interpreted by the GVC literature as to imply that targeting specific"sophisticated"products or production stages is the preferred strategy for"moving up the value chain" (Kowalski et al., 2015). This has been largely influenced by the "smiley curve" thesis' and has been interpreted to imply that it may be beneficial to move away from the assembly or manufacturing parts of the chain and has been used to justify policy objectives that seek to increase the domestic value added share. Indeed, this interpretation is in contrast with the principle of comparative advantage showing that the most profitable segments of the value chain should be jointly determined by the characteristics of the production process as well as the relative skills and resource endowments of firms and countries in question. In other words, what is important, from the point of view of the firm, is the value that is created from its economic activities and not the share that the firm occupies in the value of the final product. Furthermore, foreign and domestic value added should be seen as complement rather than substitute. This suggests that productivity may be a preferred unifying characteristic of upgrading in GVCs (Kowalski et al., 2015). This provides the rationale for investigating productivity in our empirical analysis.

Focusing on agriculture and food sectors, Greenville et al. (2019b) highlighted the presence of two possible value-adding pathways related to trade and GVC engagement. The first is a processing pathway, where domestic value addition to agriculture and links to trade and GVCs occur through downstream processing sectors. The second is a primary pathway where domestic value addition is made to the primary or raw product, and the agricultural sector's engagement in trade and GVCs is direct via the exports of these primary products for either foreign processing or foreign final demand. As in the more general debate, arguments in favour of downstream value adding are often based on the notion of higher total returns with domestic processing versus exports of primary products. However, if greater export opportunities for primary products do exist within GVCs, as does the need to add other inputs to sell into GVCs, the balance of total effects is not obvious.

1 This argument has been made in business management and refers to a graphical depiction similar to a smile where the two ends of the value chain show higher value added than the middle part of the value chain. For a deeper analysis of the smiley curve see Low (2013). 
Recently, a new strand of the international trade literature has developed global measures of the positioning of countries and industries in GVCs (see Fally, 2012; Antràs et al., 2012; Antràs and Chor, 2013; Fally and Hillberry, 2015; Alfaro et al., 2019; Miller and Temurshoev, 2017; Wang et al., 2017). Using the global Input-Output tables, with information on the various entries, it is now possible to compute more properly the implied upstreamness or downstreamness of specific industries and countries. A common approach is to consider the extent to which a countryindustry pair sells its output for final use to consumers worldwide or instead sells intermediate inputs to other producing sectors in the world. A sector that sells disproportionately to final consumers would appear to be downstream in value chains whereas a sector that sells little to final consumers is more likely to be upstream in value chains.

As for social upgrading, international outsourcing can also have positive effects on the overall level of employment. Such effects may vary depending on the industry characteristics - for example, the type of sector and the level of production sophistication - and the relative engagement in the value chain of the activities that are not outsourced. Relevant employment effects have been observed also in the agro-food sector in Southeast Asia with countries having the highest shares of workforce associated with agro-food GVCs (Lopez-Gonzalez, 2016). GVC participation is driven not only by the product characteristics, for example, individual agro-food sectors, but also by the country's economic environment, the latter impacting on potential benefits of joining global trade. Along this line, a strand of the literature has also explored the beneficial effects of trade in intermediate inputs on a country's innovation performance, through the transmission of technology and research and development (R\&D) spillovers (Tajoli and Felice, 2018; Fracasso and Marzetti, 2015; Piermartini and Rubinova, 2014). 


\section{CHAPTER 3}

Some preliminary policy insights 



\section{Some preliminary policy insights}

A large number of micro studies analyse the modalities through which emerging and developing countries enter into agri-food value chains. They underline both the importance and relative implications of tools such as contract farming with exporters/overseas buyers and standards (see, inter alia, Reardon et al., 2001; Henson et al., 2005; Swinnen, 2007; Minten et al., 2009; Handschuch, Wollni and Villalobos, 2013; Maertens and Swinnen, 2009; Swinnen, 2016).

Macro studies generally focus on import tariffs as the first obstacle to increase GVC participation and improve domestic value added (Balié et al., 2018; Greenville et al., 2017; Kowalski et al., 2015; Martinez-Zarzoso et al., 2018). Using the new EORA MRIO data, and focusing on subSaharan Africa, Balié et al. (2018) also found evidence of a further negative effect of import tariffs (that the authors qualify as a"chain effect"), that is, border protection may reduce the exported domestic value added embedded in imports through value chain linkages. This has possibly important policy implications since trade policies no longer exclusively depend on the location of the imported goods, rather on the nationality of the value added content embodied in traded goods. Consequently, there may be a need to reformulate trade policy priorities, especially in the more downstream food sector.

The emerging literature on the role of services in GVC also concludes that barriers to service trade reduce participation and domestic value added in exports. Several studies have found a positive relationship between the use of services and total factor productivity across a range of sectors, especially manufacturing (Hoekman and Shepherd, 2017; Seok and Saghaian, 2016; Arnold et al., 2011, 2015; Duggan et al., 2013). Service trade restrictiveness has been negatively associated with both imports and exports of services and with less competition on service markets (Nordås and Rouzet, 2015; Saez et al., 2015). The service sector has increased in importance as a determinant of competitiveness also in agro-food production and export costs. The availability and quality of a variety of services, including quality control, logistics, storage facilities, packaging, etc., increases the efficiency and functioning of the value chain and allows the production of more complex products (Taglioni and Winkler, 2016). Therefore, maintaining open markets for services should help the process of specialization (Lopez-Gonzalez, 2016). However, Bavarelli et al. (2017) identify the critical role of the institutions and in particular of the quality of the economic governance in shaping the positive effects that may derive from trade liberalization in services. By increasing country-level per capita incomes, greater openness to services trade has also been associated with the attainment of SDGs (Fiorini and Hoekman, 2018).

International trade of agro-food products is influenced not only by tariff and non-tariff measures and barriers to services trade, but also by the role played by domestic agricultural policies in determining the competitiveness of the sector. Distortive agricultural policies that promote subsidies for the use of inputs or subsidies outputs addressing directly the producers or the sector as a whole have been found to have a negative effect on GVC participation and on domestic value added creation (Greenville et al., 2017). Along with protectionist policies, agro-food trade faces several emerging private voluntary standards. To date, little empirical evidence exists on the relationship between private standards and a country's participation in GVCs. Though some studies have found that compliance with private standards can have positive effects on firms' trade growth and employment (Colen et al., 2012; Otsuki, 2011; Volpe-Martinicus et al., 2010), more recent evidence is mixed (Beghin et al., 2015). In particular, the critique on private standards has concentrated on its developmental implications, arguing that standards are not poor inclusive. Some empirical studies have suggested that the inclusion of smallholders in 
high-standard trade is only possible with external support from development programmes, public-private partnerships or collective action.

Furthermore, there is growing evidence that the strength of the relationship between GVC participation and economic growth depends on structural factors (for instance geography, the size of the market, the level of development, industrial structure) and policies that promote flexibility in the economies. Employment and domestic value added created from GVC participation may differ consistently depending - beyond structural factors that determine the national industry composition - on government policy settings (Greenville et al., 2017, Fagerberg et al., 2018). Along with firm strategies, local and national institutional contexts, and the role of the state intervention condition firm's upgrading opportunities and their integration in GVCs (Jurowetzki et al., 2018). Therefore, evidence suggests that the impact of trade liberalization is likely to vary depending on policies that promote economic flexibility (for example, mobility of production factors) and on conditions, such as human capital, infrastructure and the rule of law, that allow output to expand (Winters and Martuscelli, 2014). Countries, where such conditions are not in place, might be vulnerable to losses deriving from GVC participation.

As discussed above, using foreign factors in the production of agri-food exports and selling into GVC has positive effects on domestic value added creation and exports. Policies play a role in this context: the aim of policymakers should be that of creating an environment where agro-food sectors can best leverage their comparative advantages and be competitive in agrofood GVCs (Greenville et al., 2019a). In a series of studies, the OECD delineates the particular importance of trade policies in determining agro-food GVC engagement and economic growth. Protectionist policies have been found to harm development and transformation. Although put in place to aid domestic industries, tariffs may have negative impacts on growth over time (for example, increased share of value that goes to intermediates but lower returns for the producing sector). This is because it increases the costs for the domestic firms to employ the more efficient foreign inputs as well as the re-imported products. Conversely, open and non-preferential trade policies that allow for an increase in import diversity are likely to enhance the growth of agrofood sectors (Balié et al., 2018; Greenville et al., 2019a). Policy reforms in this direction could also help in terms of comparative advantage, as suggested by Greenville and Kawasaki (2018) in their analysis of the ASEAN context. In general, less complex and more transparent policy arrangements in place domestically, that avoid concerns being raised by trading partners, can increase the domestic value generated in exports (Greenville et al., 2017).

Non-distortive agricultural policies also play a role, since sectors that are free from significant subsidies and taxes have largest employment effects from participation in agro-food GVCs (Greenville et al., 2017; Greenville et al., 2019c). In line with this, promoting agricultural R\&D priorities works as an input that brings positive results in terms of domestic value added generation when exporting, given its potential for agricultural productivity growth through innovation. To this end, some studies encourage to undertake the analysis through the lens of the GVC approach and Innovation System (IS) approach in conjunction (Jurowetzki et al., 2018; Lema et al., 2018; Pietrobelli and Staritz, 2018; Pietrobelli and Rabellotti, 2011). While the GVC approach is focused on the challenges and opportunities for upgrading, the IS approach puts emphasis on firms' capability building and on the importance of national contexts to enable such capacity. Therefore, a mixed approach perspective would consider policies related to trade openness and market regulation, as well as the importance of policies aimed at improving domestic absorptive capacity through the strengthening of national innovation systems that favour knowledge exchange and firm learning. 
The ability to meet quality standards and reliability requirements have recently emerged as other important factors. Policies to support compliance with international standards and to increase trust between firms are also seen as further elements to foster GVC participation and growth. International regulatory cooperation and the convergence of standards may alleviate the burden of compliance and enhance firms' participation in global trade (Del Prete et al., 2017). Lastly, prioritizing the support of infrastructure and education are positively related to GVC participation and domestic value added creation. Transport infrastructure determines the cost of trade and the gains from trade, hence investments in construction and improvement of the quality of roads and railways open up opportunities of mobility and access to facilities. Furthermore, building the absorptive capacity of domestic actors is crucial to enable firms to benefit from knowledge and technology spillovers. On the one hand, it requires general and sector-specific policies for education, standard-setting and innovation, including initiatives such as developing public-private partnerships aimed at research and development collaboration, aligning higher education curricula and training specializations with local economic activities, or help domestic firms comply with process and product standards. On the other hand, it requires complementary policies, such as the development of horizontal cooperation through the development of effective clusters at different stages of the value chain (Taglioni and Winkler, 2016; Pietrobelli, 2008).

All these policies need to be analyzed in the context of the structural characteristics of the national system examined, including levels of development, distance from markets and agricultural land availability. For instance, a policy may play a lesser role in determining the GVC participation of low-income countries as compared to high or middle-high countries (Kowalski et al., 2015). Along this line, Pietrobelli (2008) suggests that there is ground for improving capabilities for public policy formulation and implementation, as policies to foster GVC participation need to be context-specific since general universal recipes cannot exist. 



\section{CHAPTER 4}

Methods and Data 


\section{Methods and Data}

\section{Methods}

Winters and Martuscelli (2014), in reviewing the literature on trade and poverty single out four main fields of analysis: one at the macro level, namely economic growth, and three at the microlevel, namely household outcomes, wages and labour markets and gender effects. Irwin's (2019) macro review on trade reforms and economic growth proposes three main methods of analysis: cross-country regressions, synthetic control methods on specific reform episodes, and empirical country studies to investigate the specific channels through which lower trade barriers may increase productivity.

\section{Data}

On trade in value added, inter-country input-output (ICIO) tables are now commonly used to describe the level of GVC integration of countries and industries (De Backer and Miroudot, 2014; Nagengast and Stehrer, 2016). Balié et al. (2018), for instance, to assess the impact of trade policies on GVC participation worldwide, calculate the value added embedded in gross exports using the methodology developed by Wang, Wei, and Zhu (2013), as it generalizes the accounting framework proposed by Koopman, Wang and Wei (2014) from a country-level perspective to one that decomposes gross trade flows at the sector, bilateral, or bilateral-sector level. To empirically assess the relationship between trade policy and GVC participation, Balié et al. (2018) rely on the well-established gravity model, which has been used as a workhorse for analysing the determinants of trade flows for over fifty years (Head and Mayer, 2014). In this framework, they proxy bilateral protection by using the applied tariff rate in agriculture and food of the importer country $j$ to the exporter country $i$ as well as dummy variables for the mutual participation in Free Trade Agreements (FTAs).

Nenci (2020) relies instead on Borin and Mancini (2019) extension of the Koopman et al. (2014) methodology. Borin and Mancini (2019) provide exhaustive and rigorous value-added decompositions of exports at the aggregate, bilateral and sectoral levels that are consistent with the KWW framework and overcome shortcomings that affect the KWW decomposition and other previous attempts to obtain a bilateral counterpart. Specifically, Borin and Mancini (2019) propose two different ways to account for value added in bilateral trade: the "source-based approach" that takes the perspective of the country where the value added originates and the sink-based approach that takes the perspective of the country of final demand. In both cases, the original components in KWW can be exactly retrieved by summing up the bilateral export flows across all destinations.

The overall series of OECD studies that explore the determinants and the benefits of GVC participation with different nuances, make large use of of the GTAP database, covering 141 regions across 22 agro-food sectors in 2004, 2007, 2011 and 2014. They measured GVC participation in several ways including backward and forward participation in the initial period, the share of domestic value added that ends in foreign final demand, and the concentration in imported intermediate inputs by a sector.

At the micro-level, attention has been mainly devoted to investigating the impact of firms' participation and positioning along the GVCs on firms' performance (Giovannetti et al., 2015; Rungi and Del Prete, 2018). As stated by Johnson (2018), these macro and micro approaches to measuring GVCs have advanced on parallel tracks, heading in the same direction but with 
limited overlap. However, there is scope for convergence: micro-data can improve the inputoutput approach by unveiling heterogeneity in GVC linkages across firms, whereas input-output analysis can strengthen micro-quantifications that are affected by the chronic scarcity of firmlevel data (Giunta et al., 2019).

\section{Identification strategy and instruments}

Examining the correlation between trade and income cannot identify the direction of causation between the two: countries whose incomes are high for reasons other than trade may trade more. (Frankel and Romer, 1999). Thus, to assess empirically the nexus between trade and growth we need to find alternative instruments for trade. Investigating trade and growth in the age of global value chains, Altomonte et al. (2018) provide a sound identification strategy that relies on a new geography-based and time-varying instrument for export, namely the deepwater ports able to accommodate the recent increase of container ships. Constantinescu et al. (2017) rely instead on a more workable instrument for background vertical specialization based on the assumption that the main drivers of world GVC expansion are the so-called "headquarter economies" as defined by Baldwin and Lopez-Gonzalez (2015). . Another common method to soften endogeneity stemming mainly from reverse causality (likely self-selection due to unobserved common factors driving GVC participation via productivity improvements) is to rely on lagged measures of GVC participation to subsequent medium-term (over a 5 years time span) productivity growth as well as by including variables that control for innovation activities (Gal and Witheridge, 2019). A reasonable workable extension of this is to rely on the Generalized Method of Moments (GMM) that is able to test as instruments L "moment conditions" that satisfy orthogonality (World Bank, 2020). 


\section{CHAPTER 5}

A global assessment of the linkages between both global value chain (GVC) participation (and positioning) and economic growth in the agricultural sector 



\section{A global assessment of the linkages between both global value chain (GVC) participation (and positioning) and economic growth in the agricultural sector}

The availability of fresh measures of GVCs participation and positioning from the EORA panel data for the period 1995-2015 (Nenci, 2020) provides us with an unprecedented opportunity to get a global assessment of the linkages between both GVC participation and positioning and economic performance in the agricultural sector. Since the debate on countries' participation in the global value chain deals with their performances in terms of value added, we test here the linkages between changes in global value chain participation in the agriculture and food sector and changes in value added in the agriculture sector per worker.

To this end, as in Constantinescu et al. (2017) and Gal and Witheridge (2019), we adopt a macro version of the reduced form of the standard constant returns to scale Cobb-Douglas production function with labour, land, and capital, augmented with indicators of export performance. This econometric estimation relies on a production function that expresses value-added VAc, $t$ of the agricultural sector in country $c$ and year $\mathrm{t}$ as a function of land $(L c, t)$, capital $(K c, t)$, labor $(L c, t)$, and a technology shifter $(A c, t)$. The latter is driven in part by a standard process of economic innovation and, partly, by a range of trade-related determinants $\left(\omega_{1}, \omega_{2}, \ldots, \omega_{n}\right)$ that capture both traditional trade and trade occurring in a GVC context. By dividing productivity and factors of production by labour, taking logs, and adding fixed and time effects we derive the following equation to be estimated:

$$
\theta_{c t}=\alpha_{C}+\beta_{1} k_{c t}+\beta_{2} l_{c t}+\beta_{3} g v c_{c t}+\gamma X_{c t}+\eta_{t}+\varepsilon_{i t}
$$

Where $\theta$ _ct is the country value added per worker in agriculture, forestry, and fishing (constant 2010 USD, source WDI); k_(c.t) is a measure of sectoral capital intensity (the total stock of farm machinery in 40 metric horsepower tractor equivalents per worker, source USDA); 1_(c,t) is a measure of cropland (1000 hectares of arable land plus land in permanent crops per worker, source USDA); and $g v c_{c, t}$ is a measure of GVC participation (source: Nenci, 2020). This latter represents our key variable of investigation. We test the role of GVC participation both in the agricultural sector and in the food sector. The use of the latter is justified by its importance in driving the value added for the agricultural sector as well. To give further insights into the relationship between agriculture growth and the country position along the global value chains, in an alternative empirical exercise we substituted the measure of GVC participation with measures of GVC position (Nenci, 2020). $X_{c t}$ represents a set of possible additional country controls such as a measure of technical shifts (here proxied by changes in metric tonnes of $\mathrm{N}$, P2O5, and $\mathrm{K} 2 \mathrm{O}$ nutrients for fertilizer consumption per worker, source: IFA). $\alpha_{c}$ and $\eta_{t}$ are country and time effects respectively while $\boldsymbol{\varepsilon}_{\boldsymbol{i t}}$ it is the error component.

Since we are interested in the dynamic nature of GVC specialization and performance, we employed here estimation techniques that are able to isolate the relationship between changes in explanatory variables and changes in the performance variables. In this respect, the use of panel data and an appropriate set of fixed effects restricts the identification to the within-variance of the country variables. This means that the full range of unobserved time-invariant determinants, such as, for instance, absolute and relative convergence, labour market and other institutional differences, structural differences in trade policy, time-invariant technology differences across countries and other possible time-invariant differences/confounders are all captured by the 
set of country fixed effects and thus are implicitly considered in the empirical analysis. Global changes such as global technology shocks as well as changes in the global business environment are also captured by time effects. Although the use of panels coupled with our empirical strategy is able to control for a wide set of observable and unobservable determinants as well as likely self-selection due to unobserved common factors driving GVC participation via productivity improvements, to avoid further risk of endogeneity we also lag trade-related variables by one period (and also by two periods since the effects of GVC participation on economic performance are unlikely to be instantaneous). Furthermore, we clustered standard errors by country to control for possible further error correlation bias. By interacting our GVC measures with income and geographical areas we also test for the presence of heterogeneity by country clusters.

Table 1 presents the outcomes of our baseline estimates. As expected, all the estimated coefficients of the baseline Cobb-Douglas equation are robust and positively correlated with agriculture value added per worker. Since fertilizers are here used as a proxy for technological shifts, their lack of significance shows the absence, on average, of significant impacts of technological shifts, independently from countries and/or sectoral differences in the use of fertilizers as well as possible technological shifts occurring at the country level. Our coefficients of interest (the parameters associated with both contemporary as well as lagged GVC participation indicators) are positive and statistically significant. This means that in the investigated period (1995-2105) - that we can carefully proximate to worldwide long-term elasticities - on average and ceteris paribus, there is a positive relationship between changes in agriculture value added per worker and changes in both agriculture and food GVC participation. ${ }^{3}$ In a log-log setting such as this, we can interpret the estimated coefficients as the percentage change of value added per worker associated to 1 percent change of GVC participation: for example, in the case of the contemporaneous relationship, for each 1 percent increase in GVC participation, we estimated, ceteris paribus, about 0.1 percent increase of value added per worker. It is also worth noting that this relationship shows a kind of persistence over time since it proves to be statistically significant with lagged values of GVC participation. Taking benefit of panel data, time dummies are already included in the above estimates with the specific purpose to filter out all possible covariate trend breaks. However, we also report in Table 1A in the Appendix the same estimates for the postcrisis period (2009-2015). Although those are more proximate to short-run elasticities, we can see that the positive relationship is still robust. 
Table 1

Panel estimates (period 1995-2015)

\begin{tabular}{|c|c|c|c|c|c|c|}
\hline \multirow[t]{2}{*}{ dep. Var.: agriculture value added per worker } & \multicolumn{3}{|c|}{ AGR } & \multicolumn{3}{|c|}{ FOOD } \\
\hline & GVCt & GVCt-1 & GVCt-2 & GVC† & GVCt-l & GVCt-2 \\
\hline \multirow[t]{2}{*}{ Capital intensity $(*)$} & $0.154^{* * *}$ & $0.153 * * *$ & $0.149 * * *$ & $0.149 * * *$ & $0.150 * * *$ & $0.147^{* * *}$ \\
\hline & $(0.0536)$ & $(0.0507)$ & $(0.0470)$ & $(0.0554)$ & $(0.0522)$ & $(0.0483)$ \\
\hline \multirow[t]{2}{*}{ Land intensity $(*)$} & $0.468 * * *$ & $0.450 * * *$ & $0.419 * * *$ & $0.470 * * *$ & $0.449 * * *$ & $0.418 * * *$ \\
\hline & $(0.0517)$ & $(0.0524)$ & $(0.0559)$ & $(0.0506)$ & $(0.0511)$ & $(0.0550)$ \\
\hline \multirow[t]{2}{*}{ Use of fertilizers $\left(^{*}\right)$} & 0.0353 & 0.0389 & 0.0412 & 0.0344 & 0.0381 & 0.0394 \\
\hline & $(0.0279)$ & $(0.0272)$ & $(0.0255)$ & $(0.0282)$ & $(0.0277)$ & $(0.0262)$ \\
\hline \multirow[t]{2}{*}{ Gvc participation $(* *)$} & $0.121 * *$ & $0.109 * *$ & $0.104^{* *}$ & 0.0781 * & $0.0723^{*}$ & $0.0765^{*}$ \\
\hline & (0.0480) & $(0.0466)$ & $(0.0454)$ & $(0.0426)$ & (0.0403) & (0.0394) \\
\hline \multirow[t]{2}{*}{ average fixed effects } & $6.676^{* * *}$ & $6.916 * * *$ & $6.802 * * *$ & $6.840 * * *$ & $6.887^{* * *}$ & $6.907^{* * *}$ \\
\hline & $(0.203)$ & $(0.259)$ & $(0.199)$ & $(0.217)$ & $(0.209)$ & $(0.205)$ \\
\hline Observations & 3048 & 2919 & 2790 & 3,048 & 2,919 & 2,790 \\
\hline Adj R-squared & 0.574 & 0.569 & 0.562 & 0.567 & 0.564 & 0.558 \\
\hline Number of panelid & 158 & 158 & 158 & 158 & 158 & 158 \\
\hline
\end{tabular}

To control for heterogeneity by income level, we also provide estimates by income groups for the first 10 and 25 percentiles of GNI per capita (PPP). ${ }^{4}$ As we can see from Table 2, there are no appreciable differences with Table 1 and both the low-income dummies and their interactions with GVC participation are not statistically significant. To investigate further sources of heterogeneity, we re-estimate the same equation by interacting our GVC measure with geographical regions. Figure 1 plots all the coefficients of the interactions between our measures of GVC participation in agriculture (panel a) and food (panel b) and the respective geographical regions of belonging for each country in the sample (classified according to the UN M49 classification method). The significance of these geographical dummies is reported with reference to Western Europe (acting as the benchmark category). Figure 1 shows that geography matters in explaining the heterogeneity of the relationship between changes in GVC participation and changes in agriculture value added per worker. This source of heterogeneity is higher in the case of food GVC participation and statistically significant, on average, for countries located in Eastern Europe, South America, Central Asia, Eastern Asia, Northern Africa. This heterogeneous pattern is likely determined by the different background characteristics of these geographical areas.

4 We classified countries in percentiles and interact GVC participation with dummies equal 1 for the clusters of countries with per capita GNI in the first 10 and 25 percentiles of the income distribution, alternatively. 
Panel estimates (period 1995-2015) by income groups

\begin{tabular}{|c|c|c|c|c|c|c|}
\hline \multirow[t]{2}{*}{ dep. Var:: agriculture value added per worker } & \multicolumn{3}{|c|}{ AGR } & \multicolumn{3}{|c|}{ FOOD } \\
\hline & GVCt & GVCt-1 & GVCt-2 & GVCt & GVCt-l & GVCt-2 \\
\hline \multirow[t]{2}{*}{ Capital intensity $(*)$} & $0.138 * *$ & $0.139 * * *$ & $0.136 * * *$ & $0.137^{* *}$ & $0.139 * *$ & $0.139 * * *$ \\
\hline & $(0.0565)$ & $(0.0528)$ & $(0.0482)$ & $(0.0582)$ & $(0.0541)$ & (0.0492) \\
\hline \multirow[t]{2}{*}{ Land intensity $(*)$} & $0.477 * * *$ & $0.455^{* * *}$ & $0.420 * * *$ & $0.470 * * *$ & $0.447 * * *$ & $0.411 * * *$ \\
\hline & $(0.0563)$ & $(0.0568)$ & $(0.0597)$ & $(0.0543)$ & $(0.0541)$ & $(0.0571)$ \\
\hline \multirow[t]{2}{*}{ Use of fertilizers $\left(^{*}\right)$} & 0.0346 & 0.0383 & 0.0414 & 0.0345 & 0.0385 & 0.0405 \\
\hline & $(0.0281)$ & $(0.0275)$ & $(0.0257)$ & $(0.0285)$ & $(0.0280)$ & $10.0263 \mid$ \\
\hline \multirow[t]{2}{*}{ Grc participation (**) } & $0.144^{* * *}$ & $0.130 * *$ & $0.122^{* *}$ & $0.0936 * *$ & $0.0874^{*}$ & $0.0904^{* *}$ \\
\hline & $(0.0506)$ & $(0.0503)$ & $(0.0502)$ & $(0.0470)$ & $(0.0452)$ & $(0.0452)$ \\
\hline \multirow[t]{2}{*}{ GNI pc $10 \%$ (1=yes) } & 0.199 & 0.177 & 0.162 & 0.00589 & 0.00220 & -0.0161 \\
\hline & $(0.214)$ & $(0.211)$ & $(0.206)$ & $(0.180)$ & $(0.169)$ & $(0.158)$ \\
\hline \multirow[t]{2}{*}{ GNI pc 25\% (1=yes) } & 0.0910 & 0.0952 & 0.0935 & 0.0752 & 0.0795 & 0.0741 \\
\hline & $\mid(0.159)$ & $(0.154)$ & $(0.151)$ & $(0.144)$ & (10.133) & $(0.126)$ \\
\hline \multirow[t]{2}{*}{ Gvc participation for GNI pc 10\% } & -0.0772 & -0.0715 & -0.0689 & -0.0256 & -0.0237 & -0.0158 \\
\hline & $(0.0504)$ & $(0.0498)$ & $(0.0492)$ & $(0.0491)$ & $(0.0467)$ & $(0.0445)$ \\
\hline \multirow[t]{2}{*}{ Gvc participation for GNI pc 25\% } & -0.0268 & -0.0287 & -0.0303 & -0.0342 & -0.0360 & -0.0371 \\
\hline & $(0.0287)$ & $(0.0277)$ & $(0.0266)$ & $(0.0252)$ & $(0.0237)$ & $(0.0226)$ \\
\hline \multirow[t]{2}{*}{ average fixed effects } & $6.615^{* * *}$ & $6.853^{* * *}$ & $6.767^{* * *}$ & $6.820 * * *$ & $6.868^{* * *}$ & $6.894^{* * *}$ \\
\hline & $(0.230)$ & (0.282) & $(0.237)$ & $(0.241)$ & $10.232)$ & (0.229) \\
\hline Observations & 3,048 & 2,919 & 2,790 & 3,048 & 2,919 & 2,790 \\
\hline Adj R-squared & 0.582 & 0.577 & 0.570 & 0.574 & 0.571 & 0.566 \\
\hline Number of panelid & 158 & 158 & 158 & 158 & 158 & 158 \\
\hline \multicolumn{7}{|c|}{${ }^{* * *} p<0.01,{ }^{* *} p<0.05,{ }^{*} p<0.1$ (clustered standard errors in porentheses) } \\
\hline \multicolumn{7}{|l|}{ (*) variables divided by the number of workers; } \\
\hline
\end{tabular}

Table 3 shows the estimated coefficients splitting our measure of GVC participation into its backward and forward components. ${ }^{5}$ These fresh outcomes are consistent with those in Table 1. Both backward and forward GVC participation are positively and robustly associated, on average and ceteris paribus, with changes in agriculture value added per worker. ${ }^{6}$

\footnotetext{
5 Backward participation measures imported intermediate inputs used to generate output for export. Forward participation captures the contribution of the domestic sector to the exports of other countries and indicates the extent of involvement in GVC for relatively upstream industries (Nenci, 2020).

6 Since Backward and Forward GVCs share some form of interdependence, we are forced to test them in separate regressions. The joint effect can be easily derived from the estimated coefficients for the aggregate GVC participation variable reported in Table 1. The statistical significance of the variable "fertilizers" is likely due to the omitted variable bias induced by testing a single GVC component.
} 
Figure 1

\begin{abstract}
Plot of the estimated coefficients (and the respective confidence intervals) of the relationship between agriculture value added per worker and GVC participation in agriculture (panel a) and food (panel b) by geographical clusters (Western Europe is the benchmark category) - period 1995-2015
\end{abstract}

Panel (a)

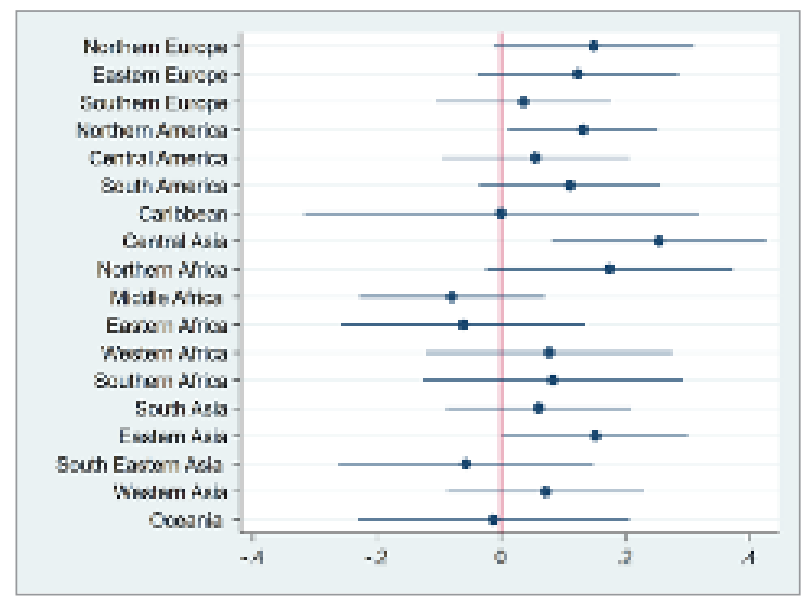

Panel (b)

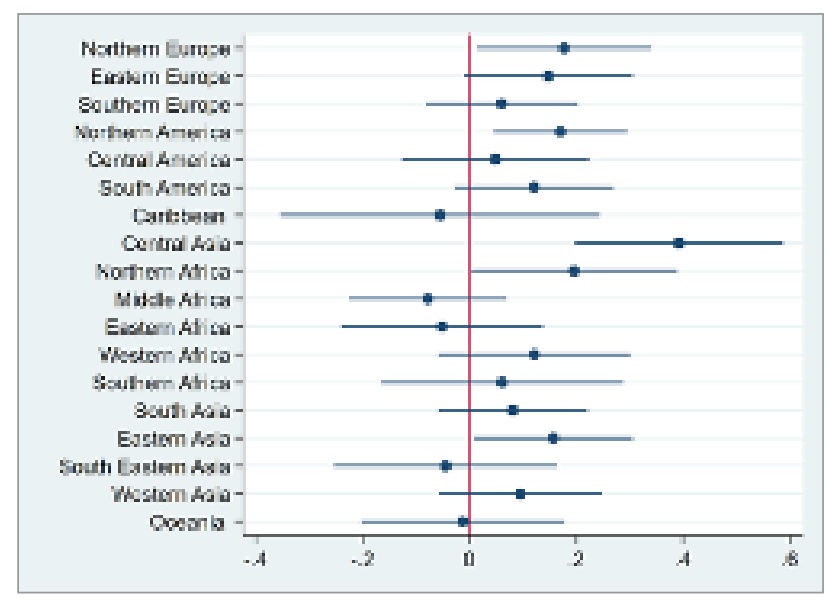

As argued in the review, the correlation between trade and income cannot identify per se a direction of causation: countries whose incomes are high for reasons other than trade may trade more (Frankel and Romer, 1999). To control for this source of endogeneity, as in Tinescu et al., 2019, we apply here a 2SLS estimation technique by instrumenting our measure of GVC participation for each country in the dataset with the GVC participation of its respective regional hub country (the United States of America for America; Germany for Europe and Africa; and China for Asia). This strategy follows on from Baldwin and Lopez-Gonzales' (2019) argument of the presence of a technological asymmetry in the international production network whereby there are "headquarter economies" and "factory economies", and the first acting as the main drivers (hubs) of the regional expansion of GVC.? Hence, the GVC participation of the "hub countries" is supposed to drive regional GVC participation and, consequently, value added on "factory economies" is only via GVC participation. This provides a workable "exclusion restriction" to identify the causal effect of GVC participation on agriculture value added in our empirical investigation. Table 4 shows the outcomes of the 2SLS estimates. The positive and statistically significant coefficients of our instrumented measure of GVC participation make us cautiously confident about the presence of a possible causal effect of GVC participation on positive variations on agriculture value added per worker. Cragg-Donald F-statistics exceeding the Stock-Yogo (2005) critical values shows that we can also be reasonably confident that our instrument is not weak.

7 In Baldwin and Lopez-Gonzales' (2015) words: "Advanced-technology headquarter economies buy and sell I2E intermediates to and from a wide range of partners. Factory economies are heavily dependent on one partner, which is always the nearest advanced-technology manufacturing giant (...) Oversimplifying, we can say that firms in the headquarter economies arrange the production networks; factory economies provide the labour." 


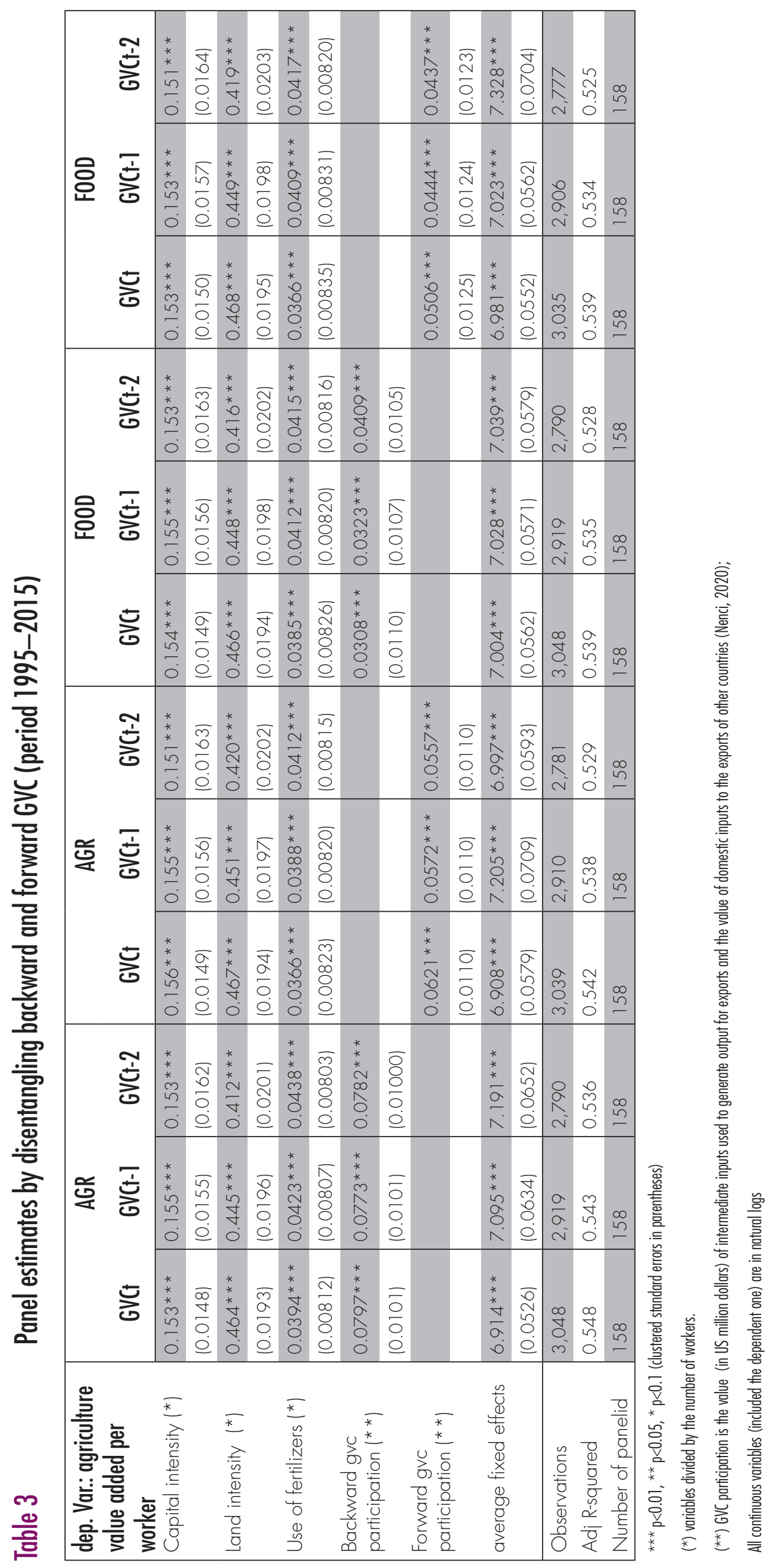


Table 4

2SLS estimates

\begin{tabular}{|c|c|c|c|c|c|c|}
\hline \multirow{3}{*}{$\begin{array}{l}\text { dep. Var.: agriculture value added per } \\
\text { worker } \\
\text { Capital intensity }\left(^{*}\right)\end{array}$} & \multicolumn{3}{|c|}{ AGR } & \multicolumn{3}{|c|}{ FOOD } \\
\hline & $\mathrm{GVCt}$ & GVCt-l & GVCt-2 & GVCt & GVCt-l & GVCt-2 \\
\hline & $0.176 * *$ & $0.170 * * *$ & $0.161 * * *$ & $0.169 * *$ & $0.160 * *$ & $0.144^{* *}$ \\
\hline \multirow{3}{*}{ Land intensity $\left({ }^{*}\right)$} & $(0.0737)$ & $(0.0648)$ & (0.0510) & (0.0800) & (0.0735) & $(0.0632)$ \\
\hline & $0.397 * * *$ & $0.382^{* * *}$ & $0.349 * * *$ & $0.409 * * *$ & $0.394^{* * *}$ & $0.363^{* * *}$ \\
\hline & $(0.0558)$ & (0.0569) & $(0.0666)$ & (0.0583) & $(0.0605)$ & $(0.0716)$ \\
\hline \multirow[t]{2}{*}{ Use of fertilizers $\left({ }^{*}\right)$} & 0.0120 & 0.0161 & 0.0192 & 0.0000694 & 0.00366 & 0.00596 \\
\hline & $(0.0288)$ & $(0.0274)$ & $(0.0250)$ & $(0.0303)$ & (0.0294) & $(0.0279)$ \\
\hline \multirow[t]{2}{*}{ Gvc participation $\left({ }^{* *}\right)$} & $0.192^{* * *}$ & $0.195^{\star * *}$ & $0.200 * * *$ & $0.183^{* * *}$ & $0.187^{* * *}$ & $0.194^{* * *}$ \\
\hline & $(0.0334)$ & $(0.0314)$ & $(0.0280)$ & $(0.0351)$ & $(0.0341)$ & $(0.0321)$ \\
\hline Observations & 1,474 & 1,411 & 1,348 & 1474 & 1411 & 1348 \\
\hline Adj R-squared & 0.510 & 0.509 & 0.509 & 0.465 & 0.461 & 0.454 \\
\hline Number of panelid & 75 & 75 & 75 & 75 & 75 & 75 \\
\hline Cragg-Donald F statistics: & 5859.865 & 4538.829 & 3553.876 & 7625.02 & 5447.227 & 4025.564 \\
\hline
\end{tabular}




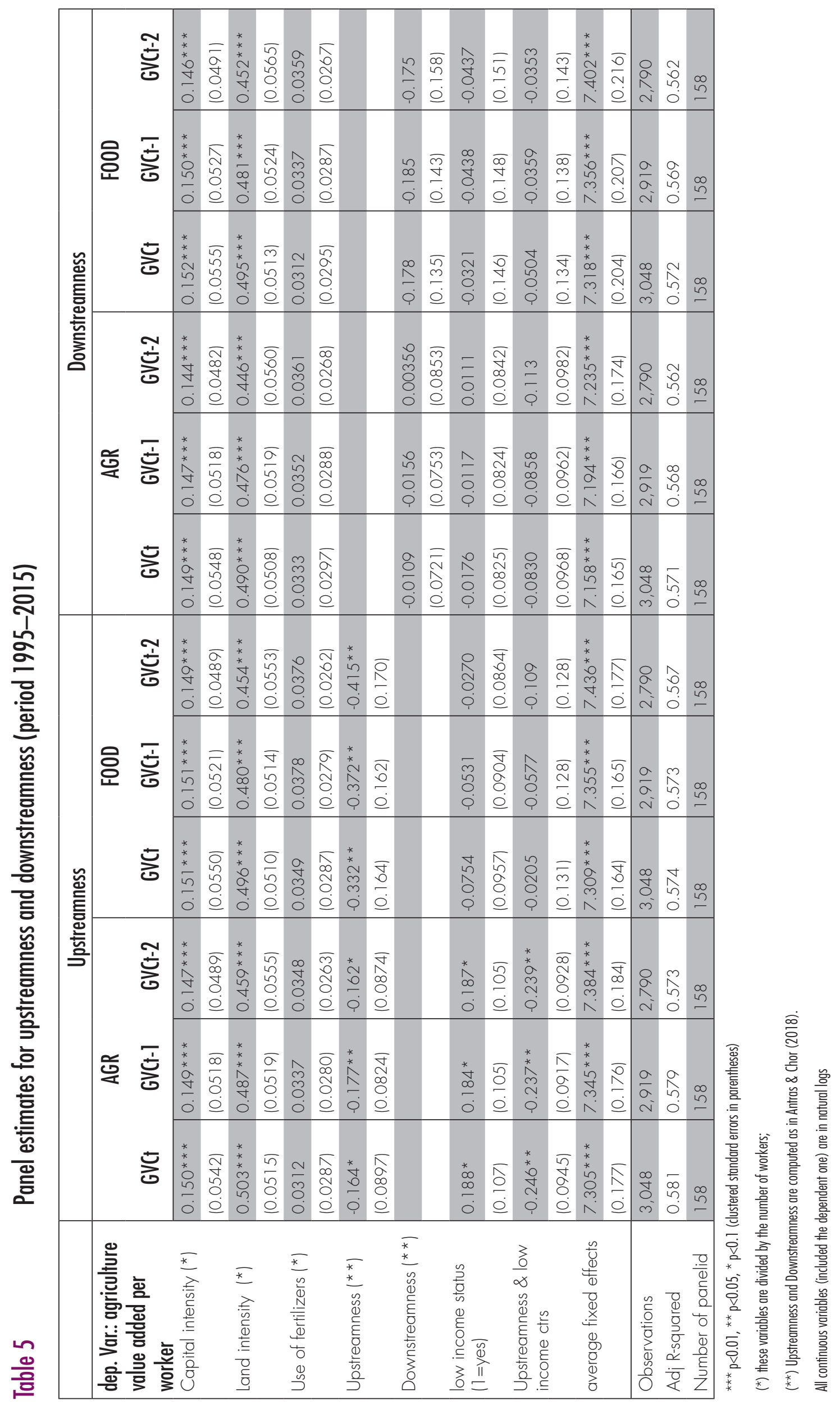


As also mentioned in the review, a hot debate in the GVC literature concerns "economic upgrading". It is generally interpreted as "moving up the value chain", that is, targeting the more "sophisticated" products or production stages which are ideally placed upstream in the value chain. In this respect, specifically in the agro-food business, policymakers are fostering local farmers' efforts to add more process to local production in order to increase local value added. However, this interpretation appears to be in contrast with the principle of comparative advantage showing that the most profitable segments of the value chain should be jointly determined by the characteristics of the production process as well as the relative skills and resource endowments of the investigated countries. To provide some insights into this complex debate, we re-run our estimates by testing the role of GVC positioning rather than just participation. To this end, in our empirical investigation we applied the two most popular measures of positioning adopted in the literature: upstreamness and downstreamness (Antràs and Chor, 2018). As for the first measure, a relatively upstream country is one that sells a small share of its output to final consumers and instead sells disproportionately to other sectors that themselves sell relatively little to final consumers. Conversely, our measure of downstreamness captures the distance of a given country production from the economy's primary factors (or sources of value-added). ${ }^{8}$

Table 5 reports the outcomes of these new estimates with positioning. It shows, on the one hand, that the relative downstreamness in the agro-food sector is not significantly associated with changes in agriculture value added, denying indirectly the rationale for upgrading. On the other hand, it shows that the relative upstreamness is negatively associated with changes in agriculture value added denoting that while upgrading is not a strategy per se, a relative distance to final markets actually hampers the domestic value added, on average and ceteris paribus. It should be noted that, also in this perspective, low-income countries do not seem to be a special case. 



\section{CHAPTER 6}

Condusive remarks 



\section{Conclusive remarks}

The common wisdom is that the emergence of GVCs represents a golden opportunity for supporting the ongoing transformations of developing countries, especially in agriculture and food markets, which could move from a subsistence-oriented and farm-centred system to a more commercialized, productive and off-farm centred one. However, the empirical evidence is mixed and relies on case studies at the product level. The availability of new aggregate data on trade in value added provides an unprecedented opportunity to carry out a global empirical assessment of the linkages between GVC participation and economic performance in the agricultural sector. We use here fresh measures of GVCs participation and positioning from the EORA panel data for the period 1995-2015 (Nenci, 2020) and test their effects on changes in agriculture value added per worker. The use of value added performance is justified by the common view that productivity is the preferred unifying characteristic for assessing countries' performance in GVCs. To this end, we apply a macro version of the reduced form of the standard constant returns to scale Cobb-Douglas production function with labour, land, capital, augmented with indicators of trade performance in value added.

Our empirical outcomes show that changes in GVC participation are, on average and ceteris paribus, positively associated with changes in agriculture value added per worker, net to timeinvariant counfounders. To be noted that backward and forward GVC participation are both positively and robustly associated with positive changes in agriculture value added per worker. This confirms, consistently with the previous literature in the field, that the effect of GVC participation on domestic value added depends on both backward and forward linkages. A further 2SLS test also makes us confident we are indeed detecting possible causality. As expected, we detect a certain degree of heterogeneity by geographical areas but not by income levels.

As a supplementary empirical test, we run fresh estimates looking at the effects of countries' positioning along the value chain. The lack of statistical significance of our measure of downstreamness confirms the lack of a theoretical rationale for moving up the value chain. In this respect, it does not seem that the "GVC revolution" has the potential to represent a completely different paradigm in trade theory. On the other hand, the robust negative association between our measures of upstreamness and agriculture value added confirms the worries of policymakers of being too far from final consumers. A reasonable policy implication of these results could be the following: moving away from final consumers is associated, on average and ceteris paribus, with a lower agriculture value added. However, it does not necessarily mean that departing from primary factors is a good strategy. This complements the Ricardian theory of comparative advantages with the well-known positive effects of being closer to the final markets, as highlighted by the literature on business organization.

This work provides some useful insights for policymaking. On the one hand, collecting the available empirical evidence on the issue as well as providing its own original estimates, it supports the view that countries' participation in GVC is, on average and ceteris paribus, positively associated with countries' economic upgrading also in the case of the agriculture sector. This complements similar established empirical evidence on manufacturing. On the other hand, it contributes to doubts about the notion of economic upgrading, showing - both theoretically and empirically - that a relative specialization in the stages of production further away from primary factors in the agro-food sector is not significantly associated with changes in agriculture value added. 
Although our fresh estimates allow us to overcome some of the structural weaknesses of the existing empirical evidence and provide robust evidence on the effects of GVC participation and position, they are not apt to derive normative implications. Taking advantage of the review of the literature in the field, we can argue however that import tariff and nontariff barriers - including barriers to service trade - should be seen as the first obstacle to increase GVC participation and improve domestic value added. In this perspective, the fact that trade policies no longer exclusively depend on the location of the imported goods, rather on the nationality of the value added content embodied in traded goods, represents the most relevant innovation in the debate and may call for a reformulation of trade policy priorities, especially in the relative downstream production (for example, the food sector). On the other hand, the role of domestic agriculture policies, as well as other possible structural factors (technological progress included), do not appear to represent a discontinuity with the standard patterns of trade. Finally, the presence of signs of heterogeneity by geographical location confirms that general universal recipes do not exist. 
REFERENCES 



\section{References}

Alfaro, L., Chor, D., Antràs, P. \& Conconi, P. 2019. Internalizing global value chains: A firmlevel analysis. Journal of Political Economy, 127(2), 508-559.

Altomonte, C., Colantone, I. \& Bonacorsi, L. 2018. Trade and growth in the age of global value chains. BAFFI CAREFIN Centre Research Paper, (2018-97).

Amiti, M. \& Konings, J. 2007. Trade Liberalization, Intermediate Inputs, and Productivity: Evidence from Indonesia. American Economic Review 97 (5): 1611-38.

Antràs, P., Chor, D., Fally, T. \& Hillberry, R. 2012. Measuring the Upstreamness of Production and Trade Flows. American Economic Review: Papers E Proceedings 102(3): 412-416.

Antràs, P. \& Chor, D. 2018. On the Measurement of Upstreamness and Downstreamness in Global Value Chains. NBER Working Papers, No. w24185, National Bureau of Economic Research, published in World trade Evolution. Growth, Productivity and Employment, ch. 5, edited by L.Yan Ing and M.Yu, Routledge, NY, 2019.

Antràs, P. \& Chor, D. 2013. Organizing the Global Value Chain. Econometrica 81(6): 2127- 2204.

Arnold, J., Javorcik B., Lipscomb M. \& Mattoo, A. 2015. Services Reform and Manufacturing Performance: Evidence from India, The Economic Journal. doi: 10.1111/ecoj.12206.

Arnold, J., Javorcik B. \& Mattoo, A. 2011. Does Services Liberalization Benefit Manufacturing Firms? Evidence from the Czech Republic, Journal of International Economics, 85, 1, 136-46.

Badinger, H. 2008. Trade Policy and Productivity, European Economic Review, Vol. 52, pp. 867891.

Baldwin, R. E. 2013. «Global supply chains: Why they emerged, why they matter, and where they are going» in D. K. Elms and P. Low (eds), Global value chains in a changing world, WTO.

Baldwin, R. \& Lopez-Gonzalez, J. 2015. Supply-chain trade: A portrait of global patterns and several testable hypotheses. The World Economy, 38(11), 1682-1721.

Balié, J., Del Prete, D., Magrini, E., Montalbano, P. \& Nenci, S. 2018. Does trade policy impact food and agriculture global value chain participation of Sub-Saharan African countries?. American Journal of Agricultural Economics, 101(3), 773-789.

Balié, J., Del Prete, D., Magrini, E., Montalbano, P. \& Nenci, S. 2019. Food and agriculture global value chains: new evidence from Sub-Saharan Africa. In Governance for Structural Transformation in Africa (pp. 251-276). Palgrave Macmillan, Cham.

Bamber, P. \& Fernandez-Stark, K. 2014. Inclusive value chain interventions in the high-value agrifood sector in Latin America. In: R. A. Hernández, J. M. Martínez-Piva and N. Mulder (eds), Global Value Chains and World Trade. Prospects and Challenges for Latin America. Santiago, Chile: Economic Commission for Latin America and the Caribbean (ECLAC), 137-162.

Barrett, C. B., Christiaensen, L., Sheahan, M. \& Shimeles, A. 2017. On the Structural Transformation of Rural Africa. Journal of African Economies, 26(suppl_1), i11-i35. https://doi. org/10.1093/jae/ejx009.

Bas, M. \& V Strauss-Kahn. 2014. Does Importing More Inputs Raise Exports? Firm-Level Evidence from France, Review of World Economics, 150(2): 241-475. 
Bavarelli, C., Fiorini, M. \& Hoekman, B. 2017. Service trade policy and manufacturing productivity: the role of institutions, Journal of International Economics, 104 (2017) 166-182

Beghin, J., Maertens, M. \& Swinnen, J. 2015. Non-tariff measures and standards in trade and global value chains. Ann. Rev. Resource Econ. 7, 425-450.

Belton, B., Haque, M. \& Little, D. C. 2011. Certifying catfish inVietnam and Bangladesh: Who will make the grade and will it matter? Food Policy. 36(2): 289-299.

Berdegué, J., Balsevich, F., Flores, L. \& Reardon, T. 2005. Central American supermarkets' private standards of quality and safety in procurement of fresh fruits and vegetables. Food Policy. 30(3): 254-269.

Borin, A. \& Mancini, M. 2019. "Measuring What Matters in Global Value Chains and ValueAdded Trade." World Bank Policy Research Working Paper 8804.

Cattaneo, O. \& Miroudot, S. 2015. From Global Value Chains to Global Development Chains: An Analysis of Recent Changes in Trade Patterns and Development Paradigms. In E. Zedillo \& B. Hoekman (Eds.), 21st Century Trade Policy: Back to the Past? Volume in Honor of Professor Patrick Messerlin. New Haven: Yale University Press.

Cattaneo, O., Gereffi, G., Miroudot, S. \& Taglioni, D. 2013. Joining, upgrading, and being competitive in global value chains. World Bank Policy Research Working Paper No. 6406.

Cline, W. R. 2004. Trade policy and global poverty. Washington (DC): Institute of International Economics.

Colen, L., Maertens M. \& Swinnen J. 2012. Private Standards, Trade and Poverty: GlobalGAP and Horticultural Employment in Senegal, The World Economy 35(8):1073-88.

Constantinescu, C., Mattoo, A. \& Ruta, M. 2019. Does vertical specialisation increase productivity?. The World Economy, 42(8), 2385-2402.

De Backer, K. \& S. Miroudot. 2014. Mapping Global Value Chains. ECB Working Paper No. 1677. Available at SSRN: https://ssrn.com/abstract=2436411.

Del Prete, D., Giovannetti, G. \& Marvasi, E. 2017. Global value chain participation and productivity gains for North African firms, Rev World Econ (2017) 153:675-701, Doi: 10.1007/ s10290-017-0292-2.

Dollar, D. \& Kraay, A. 2002. Growth is good for the poor. Journal of Economic Growth, 7(3), 195-225.

Dollar, D. \& Kraay, A. 2004. Trade, Growth and poverty. The Economic Journal, 114(493): F2249.

Dolan, C. \& Humphrey, J. 2000. Governance and trade in fresh vegetables: the impact of UK supermarkets on the African horticulture industry. Journal of Development Studies 37(2): 147-176.

Dolan, C. \& Humphrey, J. 2004. Changing governance patterns in the trade in fresh vegetables between Africa and the United Kingdom. Environment and Planning A 36(3): 491-509.

Duggan, V., Rahardja S. \& Varela, G. 2013. Service sector reform and manufacturing productivity: evidence from Indonesia, World Bank Policy Research Working Paper 6349, Washington DC: World Bank. 
Edwards, S. 1993. Openness, trade liberalisation and growth in developing countries. Journal of Economic Literature, 31, 1358-1393.

Fagerberg, J., Lundvall, B. \& Shrolec, M. 2018. Global value chains, national innovation systems and economic development, The European Journal of Development Research, July 2018, Volume 30, Issue 3, pp 533-556.

Fally, T. 2012. Production Staging: Measurement and Facts. mimeo UC Berkeley.

Fally, T. \& Hillberry, R. 2015. A coasian model of international production chains. The World Bank.

Fiorini, M. \& Hoekman, B. 2018. Service trade policy and sustainable development, World Development 112 (2018): 1-12.

Foster-McGregor, N., Kaulich, F. \& Stehrer, R. 2015. Global Value Chains in Africa. United Nations University-Maastricht Economic and Social Research Institute on Innovation and Technology (UNU-MERIT).

Fracasso, A. \& Marzetti, G. V. 2015. International trade and R\&D spillovers. Journal of International Economics, 96(1): 138-149.

Frankel, J. A. \& Romer, D. H. 1999. Does trade cause growth? . American economic review, 89(3), 379-399.

Gal, P. \& Witheridge, W. 2019. Productivity and innovation at the industry level: What role for integration in global value chains?, OECD Productivity working papers. No 19, October;

Gereffi, G. \& Lee, J. 2012. Why the world suddenly cares about global supply chains. Journal of supply chain management, 48(3), 24-32.

Gibbon, P. 2003. Value-chain governance, public regulation and entry barriers in the global fresh fruit and vegetable chain into the EU. Development Policy Review 21(5): 615-625.

Giovannetti, G., Marvasi, E. \& Sanfilippo, M. 2015. Supply chains and the internationalization of small firms. ;, 44(4), 845-865, DOI: 10.1007/s11187-014-9625-x.

Giunta, A., Montalbano, P. \& Nenci, S. 2019. The Micro and the Macro of GlobalValue Chains: evidence from European countries. Forthcoming

Goldberg, P. K. \& Pavcnik, N. 2004. Trade, inequality, and poverty: What do we know? Evidence from recent trade liberalization episodes in developing countries. Brookings Trade Forum, 223, 269.

Greenville, J., Kawasaki, K. \& Beaujeu, R. 2017. How policies shape global food and agriculture value chains. OECD Food, Agriculture and Fisheries Papers, No. 100, OECD Publishing, Paris.

http://dx.doi.org/10.1787/aaf0763a-en

Greenville, J., Kawasaki, K. \& Jouanjean, M. 2019a. Value adding pathways in agriculture and food trade: The role of GVCs and services, OECD Food, Agriculture and Fisheries Papers, No. 123, OECD Publishing, Paris. http://dx.doi.org/10.1787/bb8bb93d-en

Greenville, J., Kawasaki, K. \& Jouanjean, M. 2019b. Dynamic changes and effects of agrofood GVCs, OECD Food, Agriculture and Fisheries Papers, No. 119, OECD Publishing, Paris. http://dx.doi.org/10.1787/43b7bcec-en 
The effects of global value chain (GVC) participation on the economic growth of the agricultural and food sectors

Greenville, J., K. Kawasaki and M. Jouanjean (2019c), Employment in Agriculture and Food Trade: Assessing the Role of GVCs, OECD Food, Agriculture and Fisheries Papers, No. 124, OECD Publishing, Paris. http://dx.doi.org/10.1787/5ed3b181-en

Greenville, J. \& Kawasaki, K. 2018. Agro-food trade, GVCs and agricultural development in ASEAN, OECD Food, Agriculture and Fisheries Papers, No. 116, OECD Publishing, Paris. http:// dx.doi.org/10.1787/89d40ebb-en.

Grossman, G. M. \& Rossi-Hansberg, E. 2008. Trading tasks: a simple theory of offshoring. American Economic Review 98(5): 1978-1997.

Kasahara, H. \& Rodrigue, J. 2008. Does the Use of Imported Intermediates Increase Productivity? Plant-Level Evidence. Journal of Development Economics 87 (1): 106-18.

Koopman, R., Wang, Z. \& Wei, S. J. 2014. Tracing Value-Added and Double Counting in Gross Exports. American Economic Review, 104(2), 459-494.

Kowalski, P., Lopez-Gonzalez, J., Ragoussis, A. \& Ugarte, C. 2015. Participation of developing countries in GlobalValue Chains: Implications for trade and trade-related policies, OECD Trade Policy Papers, No. 179, OECD Publishing, Paris. http://dx.doi.org/10.1787/5js33lfw0xxn-en

Kummritz, V. 2015. Global Value Chains: Benefitting the Domestic Economy? CTEI Working Papers, CTEI-2014-05.

Handschuch, C., Wollni, M. \& Villalobos, P. 2013. Adoption of food safety and quality standards among Chilean raspberry producers. Do smallholders benefit? Food Policy. 40: 64-73.

Halpern, L., Koren, M. \& A. Szeid1. 2015. Imported Inputs and Productivity, American Economic Review, 105(12): 3660-3703.

Halpern, L., Koren, M. \& Szeidl, A. 2011. Imported Inputs and Productivity. CeFiG Working Papers 8, Center for Firms in the Global Economy, revised 16 Sep 2011.

Hazell, P., Poulton, C., Wiggins, S. \& Dorward, A. 2010. The future of small farms: trajectories and policy priorities. World Development 38(10): 1349-1361.

Head K. \& Mayer, T. 2014. Gravity equations: Workhorse, toolkit and cookbook. In: Gopinath G., Helpman E., Rogoff K. (ed.), Handbook in International Economics, Vol. 4 of Handbook of International Economics, Elsevier, pp. 131-195.

Henson, S., Masakure, P. \& Boselie, D. 2005. Private food safety and quality standards for fresh produce exporters: the case of Hortico Agrisystems, Zimbabwe. Food Policy, 30(4): 371-384.

Hoekman, B. \& Shepherd, B. 2017. Service productivity, trade policy and manufacturing exports, The world Economy. doi: 10.1111/twec.12333.

Humphrey, J. \& Schmitz, H. 2002. "How does insertion in global value chains affect upgrading in industrial clusters?", Regional Studies, Vol. 36(9), pp. 1017-1027.

Humphrey, J. \& Memedovic, O. 2006. Global Value Chains in the Agrifood Sector. Working Paper, United Nations Industrial Development Organization. Vienna;

International Monetary Fund. 2015. Regional Economic Outlook. SubSaharan Africa. Washington, DC: International Monetary Fund. 
Irwin, D.A. 2019. Does trade reform promote economic growth? A review of recent evidence. NBER Working paper 25927.

Jaffee, S. \& Masakure, O. 2005. Strategic use of private standards to enhance international competitiveness: vegetable exports from Kenya and Elsewhere. Food Policy. 30(3): 316-333.

Johnson, R. C. 2018. Measuring global value chains. Annual Review of Economics, 10, 207-236.

Jurowetzki, R., Lema, R. \& Lundvall, B-Å. 2018. Combining Innovation Systems and Global Value Chains for Development: Towards a Research Agenda. European Journal of Development Research, 30(3), 364-388. https://doi.org/10.1057/s41287-018-0137-4

Lee, J., Gereffi, G. \& Beauvais, J. 2012. Global value chains and agrifood standards: challenges and possibilities for smallholders in developing countries. Proceedings of the National Academy of Sciences 109(31): 12326-12331.

Lema, R., Rabellotti, R. \& Gehl Sampath, P. 2018. Innovation trajectories in developing countries: Co-evolution of global value chains and innovation systems, The European Journal of Development Research (2018) 30, 345-363. https://doi.org/10.1057/s41287-018- 0149-0;

Lim, S. 2019. Global Agricultural Value Chains and Structural Transformation. Staff Paper Series P19-4. Department of Applied Economics, University of Minnesota (USA);

Lopez Gonzalez, J. 2016. Using Foreign Factors to Enhance Domestic Export Performance: A Focus on Southeast Asia, OECD Trade Policy Papers, No. 191, OECD Publishing, Paris. http:// dx.doi.org/10.1787/5jlpq82v1jxw-en.

Low, P. 2013. "The role of Services in Global Value Chains", in Elms, D. and P. Low, (2013) Changing value chains in a changing world, WTO publications.

Lundberg, M. \& Squire, L. 2003. The simultaneous evolution of growth and inequality. Economic Journal, 113(487), 326-344.

Maertens, M. \& Swinnen, J. F. M. 2009. Food standards, trade and development. Review of Business and Economics. 54(3): 313-326.

Martinez-Zarzoso, I.; Said, M. \& Zaki, C. 2018. Trade policy and input liberalization: the effect of Egyptian's firm productivity, Working Paper No. 1238, The Economic Research Forum (ERF).

McCulloch, N., Winters, L. A. \& Cirera, X. 2001. Trade liberalization and poverty: A handbook. London: Centre of Economic Policy Research.

McCullough, E., Pingali, P. \& Stamoulis, K. (eds). 2008. The Transformation of Agri-Food Systems: Globalization, Supply Chains and Smallholder Farmers. London, UK: Earthscan.

Meissner, C.M. 2014. Growth from globalization? A view from the very long run, Handbook of Economic Growth, Vol. 2B, Chapter 8, 1033-1069.

Milberg, W. \& D. Winkler. 2010. "Trade crisis and recovery: restructuring of global value chains", Policy Research Working Paper Series, No 5294, The World Bank.

Miller, R., E. \& Temurshoev, U. 2017. Output Upstreamness and Input Downstreamness of Industries/Countries in World Production. International Regional Science Review 40(5): 443-475.

Minten, B., Randrianarison, L. \& Swinnen, J. F. M. 2009. Global retail chains and poor farmers: Evidence from Madagascar. World Development, 37(11): 1728-1741. 
Montalbano, P. 2011. Trade openness and developing countries' vulnerability: concepts, misconceptions, and directions for research. World Development, 39(9), 1489-1502.

Montalbano, P., Pietrelli, R. \& Salvatici, L. 2018a. Participation in the market chain and food security: The case of the Ugandan maize farmers. Food Policy, 76, 81-98.

Montalbano, P., Nenci, S. \& Pietrobelli, C. 2018b. Opening and linking up: firms, GVCs, and productivity in Latin America, Small Bus Econ (2018) 50:917-935, DOI 10.1007/s11187-0179902-6.

Nadvi, K. 2004. Globalization and Poverty: how can the global value chain research inform the policy debate?, IDS Bulletim N. 35.

Nagengast, A. J. \& Stehrer, R. 2016. Accounting for the differences between gross and value added trade balances. The World Economy, 39(9), 1276-1306.

Nordås, H.K. \& D. Rouzet. 2015. The Impact of Services Trade Restrictiveness on Trade Flows: First Estimates, OECD Trade Policy Papers, No. 178, OECD Publishing, Paris, http://dx.doi. org/10.1787/5js6ds9b6kjb-en.

OECD. 2016. Evolving Agricultural Policies and Markets: Implications for Multilateral Trade Reform. Paris: OECD Publishing.

Olper, A., D. Curzi \& V. Raimondi. 2015. Import Penetration, Intermediate Inputs and Firms' Productivity in the EUFood Industry, 2015 Allied Social Sciences Association (ASSA) Annual Meeting, January 3-5, 2015, Boston, Massachusetts.

Otsuki, T. 2011. Effect of International Standards Certification on Firm-Level Exports: An Application of the Control Function Approach", Osaka School of International Public Policy Discussion Paper No. 11E005

Piermartini, R. \& Rubinova, S. 2014. Knowledge Spillovers Through International Supply Chains. WTO Staff Working Papers ERSD-2014-11.

Pietrobelli, C. \& Staritz, C. 2018. Upgrading, Interactive Learning, and Innovation Systems in Value Chain Interventions. European Journal of Development Research, 30(3), 557-574. https:// doi.org/10.1057/s41287-017-0112-5

Pietrobelli, C. \& Rabellotti, R. 2011. Global value chains meets innovation systems: are there learning opportunities for developing countries? World Development, 29(7): 1261-1269.

Pietrobelli, C. 2008. Global value chains in the least developed countries of the world: Threats and opportunities for local producers. International Journal of Technological Learning, Innovation and Development 1(4): 459-481.

Rao, E. \& Qaim, M. 2011. Supermarkets, farm household income, and poverty: insights from Kenya. World Development. 39(5): 784-796.

Rao, E., Brummer, B. \& Qaim, M. 2012. Farmer participation in supermarket channels, production technology, and efficiency: the case of vegetables in Kenya. American Journal of Agricultural Economics 94(4): 891-912.

Reardon, T., Codron, J. M., Busch, L., Bingen, J. \& Harris, C. 2001. Global change in agrifood grades and standards: agribusiness strategic responses in developing countries. International 
Food and Agribusiness Management Review. 2(3-4): 421-435.

Reardon, T., Barrett, C. B., Berdegué, J. A. \& Swinnen, J. F. 2009. Agrifood industry transformation and small farmers in developing countries. World Development 37(11): 17171727.

Rungi, A. \& Del Prete, D. 2018. The smile curve at the firm level: Where value is added along supply chains. Economics Letters, 164, 38-42.

Sachs, J. D. \& Warner, A. M.1995. Economic reform and the process of global integration. Brookings Papers on Economic Activity, 1, 1-95.

Saez, J. S., Hollweg, C. H., Taglioni, D., van der Marel, E., Leendert, E. \& Zavacka, V. 2015. Valuing services in trade: A toolkit for competitiveness diagnostics. Technical Report 93714, The World Bank.

Salvatici, L. \& Nenci, S. 2017. New features, forgotten costs and counterfactual gains of the international trading system. European Review of Agricultural Economics, 44(4), 592-633.

Seok, J.H. \& Saghaian, S.H. 2016. Does Service Trade Liberalization Benefit Agriculture and Food Industry?, Paper presented at the Southern Agricultural Economics Association's Annual Meeting, San Antonio, Texas, 6-9 February 2016.

Swinnen, J. 2007. Global Supply Chains, Standards and the Poor: How the Globalization of Food Systems and Standards Affects Rural Development and Poverty. Oxon, UK: CABI Publishing, 91-108.

Swinnen, J. 2016. Economics and politics of food standards, trade, and development. Agricultural Economics 47: 7-19.

Swinnen, J. F. 2014. Global Agricultural Value Chains, Standards, and Development. http:// cadmus.eui.eu/bitstream/handle/1814/31334/RSCAS_2014_30.pdf.

Swinnen, J. \& Vandeplas, A. 2014. Price transmission and market power in modern agricultural value chains. LICOS Discussion Paper No. 347.

Swinnen, J. \& Kuijpers, R. 2017.Value chain innovations for technology transfer in developing and emerging economies: conceptual issues, typology, and policy implications. Food Policy 83: 298-309.

Taglioni, D. \& Winkler, D. 2016. Making Global Value Chains Work for Development, Trade and Development series. Washington, DC: World Bank. doi:10.1596/978-1-4648-0157-0.

Tajoli, L. \& Felice, G. 2018. Global value chain participation and knowledge spillovers in developed and developing countries: an empirical investigation, The European Journal of Research Development, 30, 505-532. doi.org/10.1057/s41287-017-0127-y;

Topalova, P.\& Khandelwal, A. 2011. Trade Liberalization and Firm Productivity: The Case of India. Review of Economics and Statistics 93 (3): 995-1009.

Volpe-Martincus, C., Castresana, S. \& Castagnino, T. 2010. ISO Standards: A Certificate to Expand Exports? Firm-Level Evidence from Argentina, Review of International Economics, 18(5): 896-912.

Wang, Z., Wei, S.-J. \& Zhu, K. 2013. Quantifying International Production Sharing at the Bilateral and Sector Levels. National Bureau of Economic Research. 
Wang, Z.,Wei, S., Yu, X. \& Zhu, K. 2017. Measures of Participation in Global Value Chains and Global Business Cycles. National Bureau of Economic Research (NBER) Working Paper 23222.

Winters, LA. 2004. Trade liberalisation and economic performance: an overview. The Economic Journal. 114(493):F4-21;

Winters, L. A., McCulloch, N. \& McKay, A. 2004. Trade liberalization and poverty: The evidence so far. Journal of Economic Literature, 42(1), 72-115.

Winters, LA. \& Martuscelli, A. 2014. Trade Liberalization and Poverty: What have we learned in a decade?. Annual Review of Resource Economics, Annual Reviews, vol. 6(1), pages 493-512, October;

World Bank. 2020. World Development Report. Trading for Development in the Age of Global Value Chains. 
APPENDIX 



\section{Appendix A - Tables}

Table Al

Panel estimates (period 2009-2015)

\begin{tabular}{|c|c|c|c|c|c|c|}
\hline \multirow[t]{2}{*}{ dep. Var.: agriculture value added per worker } & \multicolumn{3}{|c|}{ AGR } & \multicolumn{3}{|c|}{ FOOD } \\
\hline & GVCt & GVCt-l & GVCt-2 & GVCt & GVCt-l & GVCt-2 \\
\hline \multirow[t]{2}{*}{ Capital intensity $\left({ }^{*}\right)$} & $0.212 * *$ & $0.205^{* *}$ & $0.203 * *$ & $0.215^{* *}$ & $0.214^{* *}$ & $0.211 * *$ \\
\hline & $(0.0905)$ & $(0.0913)$ & (0.0927) & (0.0903) & $(0.0911)$ & (0.0919) \\
\hline \multirow[t]{2}{*}{ Land intensity $\left({ }^{*}\right)$} & $0.408 * * *$ & $0.420 * * *$ & $0.413 * * *$ & $0.399 * * *$ & $0.405^{* * *}$ & $0.404 * * *$ \\
\hline & $(0.102)$ & $|0.103|$ & $|0.103|$ & $(0.0991)$ & $(0.101)$ & $(0.102)$ \\
\hline \multirow[t]{2}{*}{ Use of fertilizers $\left({ }^{*}\right)$} & 0.00918 & 0.0104 & 0.0147 & 0.0148 & 0.0139 & 0.0137 \\
\hline & $(0.0186)$ & $(0.0200)$ & (0.0209) & $(0.0211)$ & $(0.0214)$ & $(0.0212)$ \\
\hline \multirow[t]{2}{*}{ Gvc participation (**) } & $0.218 * * *$ & $0.176 * * *$ & $0.123 * *$ & $0.179 * * *$ & $0.139 * *$ & $0.105 * *$ \\
\hline & (0.0705) & $(0.0635)$ & $(0.0616)$ & (0.0670) & $(0.0578)$ & $(0.0494)$ \\
\hline \multirow[t]{2}{*}{ average fixed effects } & $6.407 * * *$ & $6.601 * * *$ & $6.869 * * *$ & $6.555^{* * *}$ & $6.748 * * *$ & $6.936 * * *$ \\
\hline & $(0.376)$ & $(0.385)$ & $(0.393)$ & $(0.395)$ & $(0.397)$ & $(0.383)$ \\
\hline Observations & 1090 & 1090 & 1090 & 1090 & 1090 & 1090 \\
\hline Adj R-squared & 0.395 & 0.393 & 0.389 & 0.393 & 0.391 & 0.388 \\
\hline Number of panelid & 158 & 158 & 158 & 158 & 158 & 158 \\
\hline
\end{tabular}

${ }^{* \star *} p<0.01,{ }^{* \star} p<0.05,{ }^{*} p<0.1$ (clustered standard errors in parentheses)

${ }^{*}$ ) variables divided by the number of workers;

${ }^{(*)}$ GVC participation is the value (in USD million) of intermediate inputs used to generate output for exports and the value of domestic inputs to the exports of other countries (Nenci, 2020).

All continous variables (included the dependent one) are in natural logs 




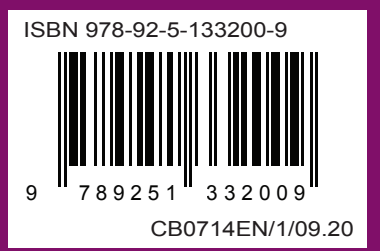

